\title{
Pembuatan Aplikasi Catalog 3D Desain Rumah Sebagai Sarana Promosi Dengan Menggunakan Unity 3D
}

\author{
Siryantini Nurul Adnin ${ }^{1}$, Ida Bagus Ketut Widiartha ${ }^{2}$, I Made Budi Suksmadana ${ }^{3}$ \\ Jurusan Teknik Elektro, Fakultas Teknik Universitas Mataram, Nusa Tenggara Barat \\ 1'iningnining@gmail.com \\ 2widi@ftunram.ac.id \\ ${ }^{3}$ mdbudi@yahoo.com
}

\begin{abstract}
Abstrak
Penelitian ini memasukkan teknologi AR ke dalam Catalog penjualan rumah, sehingga Catalog rumah ini menjadi lebih real dengan adanya objek $3 D$ di dalamnya. Penelitian ini bertujuan untuk menghasilkan sebuah aplikasi yang dapat menampilkan model rumah 3D sehingga dapat membantu para pembeli untuk mengetahui dengan baik rumah yang akan dibeli, serta akan mempermudah seller rumah sebagai media promosi kepada konsumen. Untuk pembuatan objek 3D digunakan dua macam Software yaitu Sweet Home 3D dan Blender, sedangkan untuk membuat aplikasi dalam pemograman (Coding) digunakan Software Unity 3D dengan menggunakan bahasa pemograman C\#. Aplikasi Catalog Desain Rumah ini dibuat melalui beberapa tahapan yaitu pembuatan objek 3D, pembuatan marker dan perancangan aplikasi. Hasil akhirnya terdiri dari dua bentuk yaitu dalam bentuk fisik (Media cetak berupa Catalog) yang berisikan marker pada beberapa halamannya dan aplikasi Augmented Reality berbasis Android dalam bentuk .apk yang kemudian diinstal pada Smartphone, dimana keduanya saling melengkapi.
\end{abstract}

Kata Kunci: Augmented Reality, Unity, Marker, C\#, Catalog.

\begin{abstract}
This study incorporate AR into a technology home Catalog sales, thus Catalog home is becoming more real with $3 D$ objects in it. This research aims to produce an application that can display a 3D model of a house that can help buyers to know well the home to be purchased, and will simplify the home seller as a media campaign to consumers. $3 D$ objects used to develop two kinds of Software that Sweet Home 3D and Blender, whereas to create application in programming used Unity $3 D$ Software using the $C$ \# programming language. Application home design Catalog is made through several stages of design 3D objects, Marker workmanship and application design. The end result consists of two forms, namely in the form of physical (in the form of print media Catalog) that contains a marker on some pages and Augmented Reality applications based on Android in the form of .apk which is then installed on Smartphones, where the two are complementary.
\end{abstract}

Keywords: Augmented Reality, Unity, Marker, C \#, Catalog.

\section{Pendahuluan}

Bisnis properti saat ini memang sedang menjamur dikota-kota besar dan kecil karena mempunyai keuntungan yang cukup besar [1]. Dengan memanfaatkan teknologi Augmented Reality sebagai salah satu cara alternatif dalam melakukan promosi, konsumen akan dapat melihat tampilan rumah secara 3D yang terdapat pada Catalog, sehingga rumah yang tampilkan akan terlihat lebih detil dan nyata. Tidak hanya itu, pada aplikasi katalog rumah ini pembeli juga dapat melihat bagian rumah dengan detail, tetapi juga dapat melihat denah rumah dengan tampilan 3 dimensi. 


\section{Metodologi Penelitian}

\subsection{Rancangan Sistem Aplikasi}

Pada sistem yang diberikan QCAR, semua simulasi tersebut dapat diformat dalam sebuah aplikasi yang dijalankan pada perangkat Android dengan Unity sebagai editor.

Dari blok diagram Gambar 1 terlihat tahapan-tahapan dalam merender grafis, yaitu:

a. Dimulai dengan Inisialisasi kamera.

b. Gambar dari kamera kita per-frame, kemudian menghasilkan "Camera-frame".

c. Fitur yang ada pada Marker.

d. Menemukan Target.

e. Melihat apa-apa saja Menu yang terdapat pada Marker.

f. Data yang terdapat pada Marker apakah termasuk dalam Image target, Multi, serta ada

a. atau tidak adanya virtual button dan virtual button 3D.

g. Mengolah object yang tersimpan.

h. Aplikasi menquery object.

i. App logicnya untuk bisa menampilkan object. Logika aplikasi (if else Marker A, B, C).

j. Objek 3D sesuai dengan Logika [2].

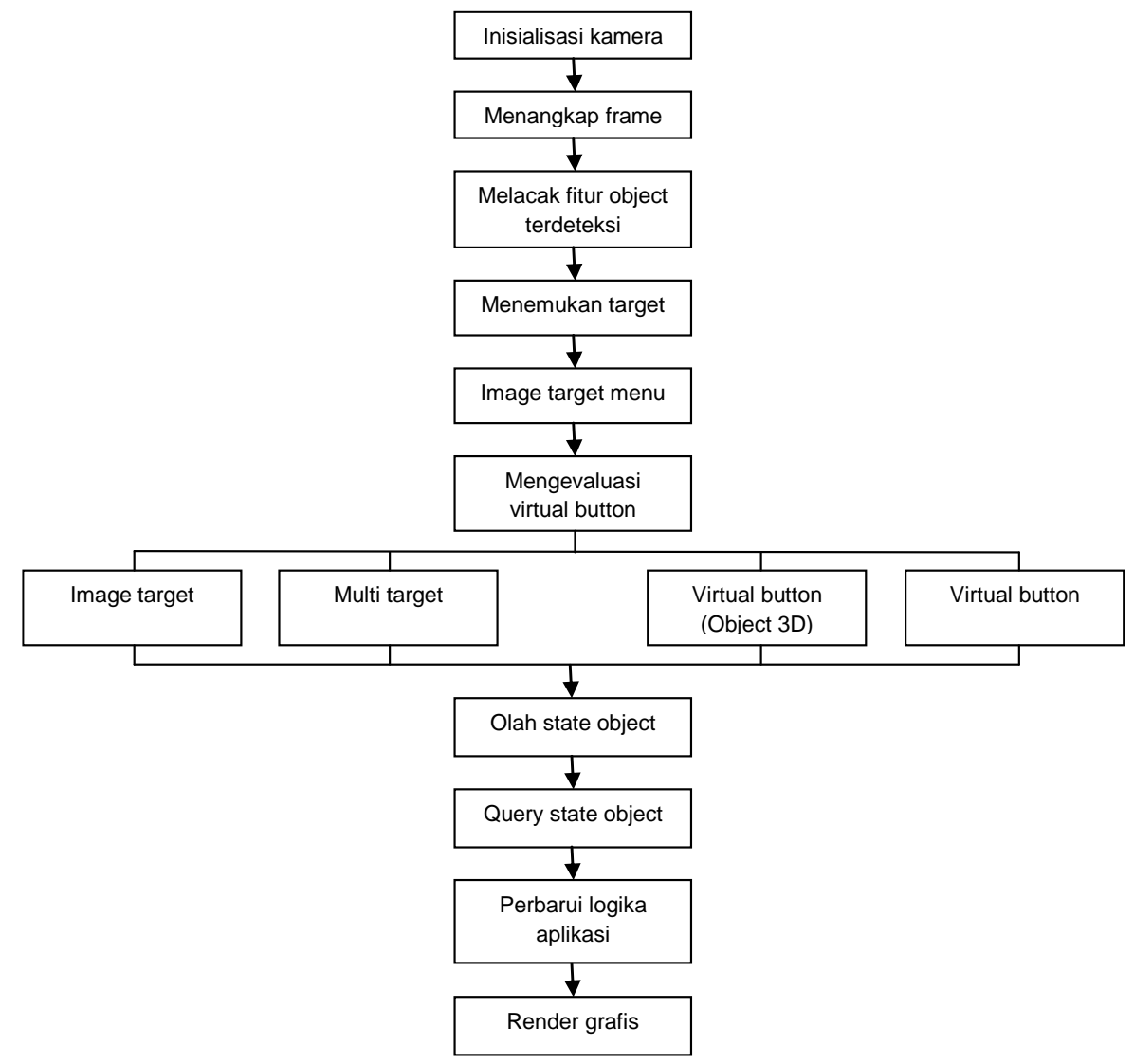

Gambar 1. Diagram Blok Aplikasi

\subsection{Perancangan Aplikasi}

Tahapan-tahapan persiapan yang mesti dilakukan antara lain :

a. Persiapan Awal

Langkah-langkah dalam persiapan Pembuatan 3D Catalog design rumah, adalah sebagai berikut:

1. Membuat 3D object menggunakan Tools Software 3D yaitu Sweet Home 3D dan Blender. 
2. Membuat Marker pada tiap-tiap halaman Catalog kemudian registrasikan pada http://developer. Vuforia.com.

3. 3D object animasi dalam format .obj atau .fbx dan kemudian melakukan perekayasaan dengan Unity $3 D$ [3].

b. Rancangan Tampilan Antar Muka (Interface)

1. Tampilan Awal Aplikasi

Halaman ini merupakan halaman awal atau pembuka dari aplikasi 3D Catalog. Rancangan tampilan awal aplikasi seperti dapat dilihat seperti pada Gambar 2 dibawah ini.

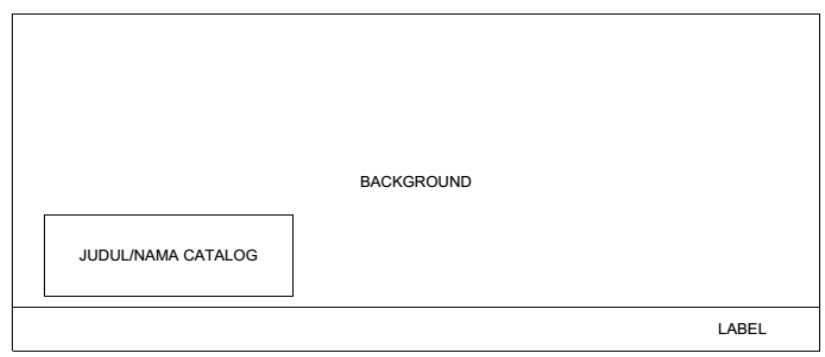

Gambar 2. Tampilan awal Aplikasi

2. Tampilan Menu Utama Aplikasi

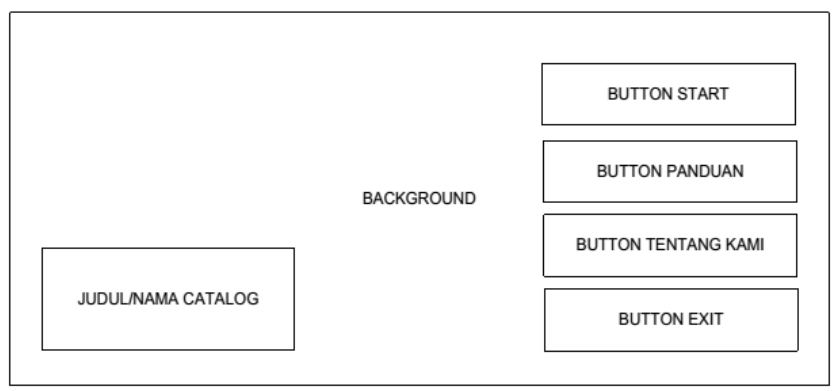

Gambar 3. Tampilan Menu Utama Aplikasi

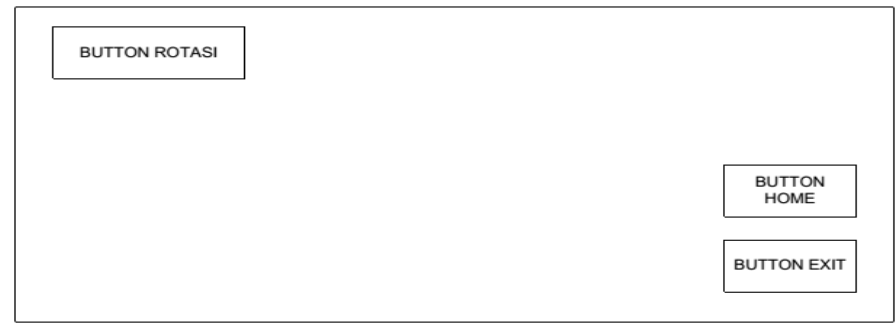

Gambar 4. Tampilan Saat Button Start dipilih

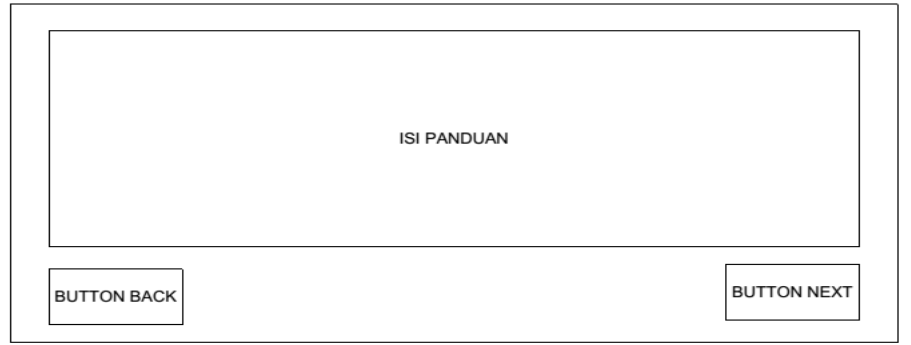

Gambar 5. Tampilan Saat Button Panduan dipilih 


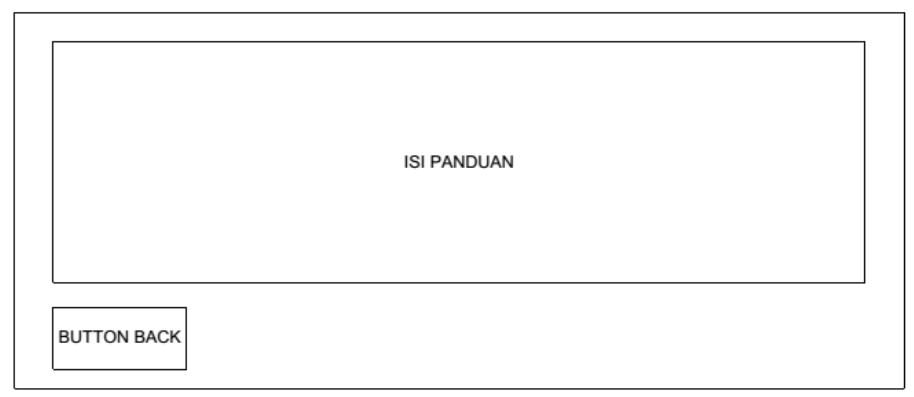

Gambar 6. Tampilan Saat Button Next dipilih

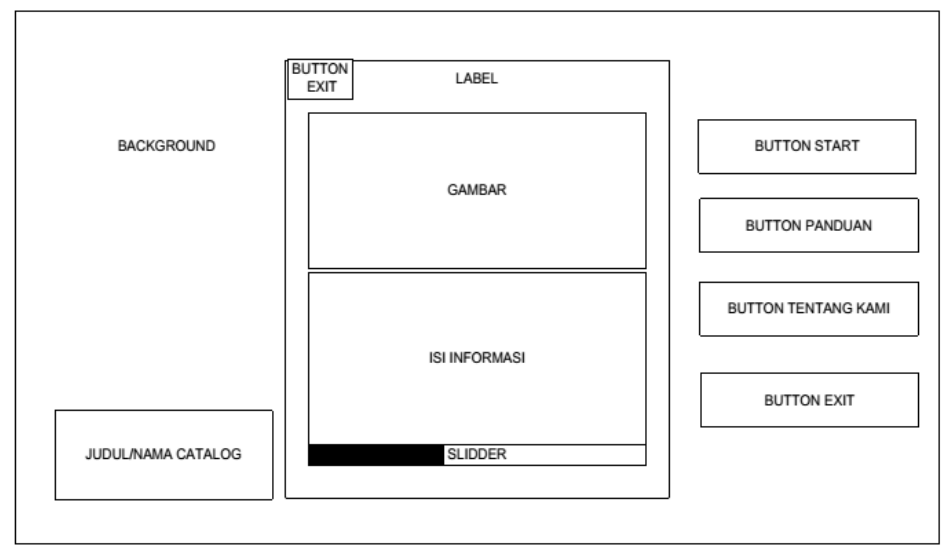

Gambar 7. Tampilan Saat Button Tentang Kami dipilih

\section{c. Proses Perekayasaan (Coding)}

Perekayasaan (Coding) dalam pembuatan aplikasi ini menggunakan Unity $3 D$ Versi 3.3.0 dengan Vuforia Unity Plugins Versi 2.8.7. Coding dilakukan dalam setiap tampilan Scene atau halaman untuk membuat tampilan antar muka (Interface) berupa GUI lebih menarik. Pada Class Hierarchy Vuforia terdapat class-class turunan dari Vuforia. Namun pada pengerjaan aplikasi Catalog 3D ini tidak semua class digunakan dikarenakan tidak semua dibutuhkan, sehingga hanya class yang dibutuhkan saja yang akan digunakan. Class- class tersebut antara lain :

1. Vuforia.DefaultInitializationErrorHandler

2. DataSetLoadBehaviour

3. Vuforia.KeepAliveBehaviour

4. Vuforia.DefaultTrackableEventHandler

5. Vuforia.QCARBehaviour

6. Vuforia.TurnOffBehaviour, dan

7. Vuforia.ImageTargetBehaviour

- Class Diagram

Class Diagram menggambarkan hubungan antara kelas yang ada pada aplikasi Catalog 3D Desain Rumah ini. Class dapat merupakan implementasi dari sebuah Interface, yaitu Class abstrak yang hanya memiliki metode. Interface tidak dapat langsung diinstansiasikan, tetapi harus diimplementasikan dahulu menjadi sebuah Class [4].

d. Proses Pengujian Aplikasi.

Pada proses pengujian ini aplikasi diuji dengan melihat apakah aplikasi dapat berjalan dengan baik pada Smartphone Android dan sesuai dengan rancangan dan tujuan yang telah dibuat. 


\section{Kajian Pustaka}

\subsection{Pengertian 3D Catalog}

3D Catalog adalah sebuah katalog yang dapat menampilkan model animasi 3D dengan cara melakukan pembacaan simbol ataupun gambar Marker menggunakan kamera sebagai media inputan. Catalog berbasis Augmented Reality ini sendiri hasil akhirnya terdiri dari dua format yaitu dalam format fisik (media cetak berupa Catalog) yang berisikan Marker pada beberapa halamannya dan aplikasi Augmented Reality berbasis Android dimana keduanya saling melengkapi.

\subsection{Augmented Reality}

Augmented Reality sebagai penggabungan benda-benda nyata dan maya di lingkungan nyata, berjalan secara interaktif dalam waktu nyata, dan terdapat integrasi antar benda dalam tiga dimensi, yaitu benda maya terintegrasi dalam dunia nyata. Marker merupakan sebuah gambar atau symbol yang sudah dikenali oleh template database. Dimana Marker tersebut berfungsi untuk dibaca dan dikenali oleh kamera lalu dicocokkan dengan template pada suatu Software perekayasaan. Setelah itu, baru kamera akan melakukan render objek 3D diatas Marker. Vuforia adalah Augmented Reality Software Development Kit (SDK) untuk perangkat mobile yang memungkinkan pembuatan aplikasi Augmented Reality. Dulunya lebih dikenal dengan QCAR (Qualcomm Company Augmentend Reality). QCAR menggunakan teknologi Computer Vision untuk mengenali dan melacak gambar planar (Target Image) dan objek 3D sederhana, seperti kotak, secara real-time. Alur proses yang terjadi pada pelacakan QCAR dapat dilihat pada blok diagram pada Gambar 8 berikut ini.

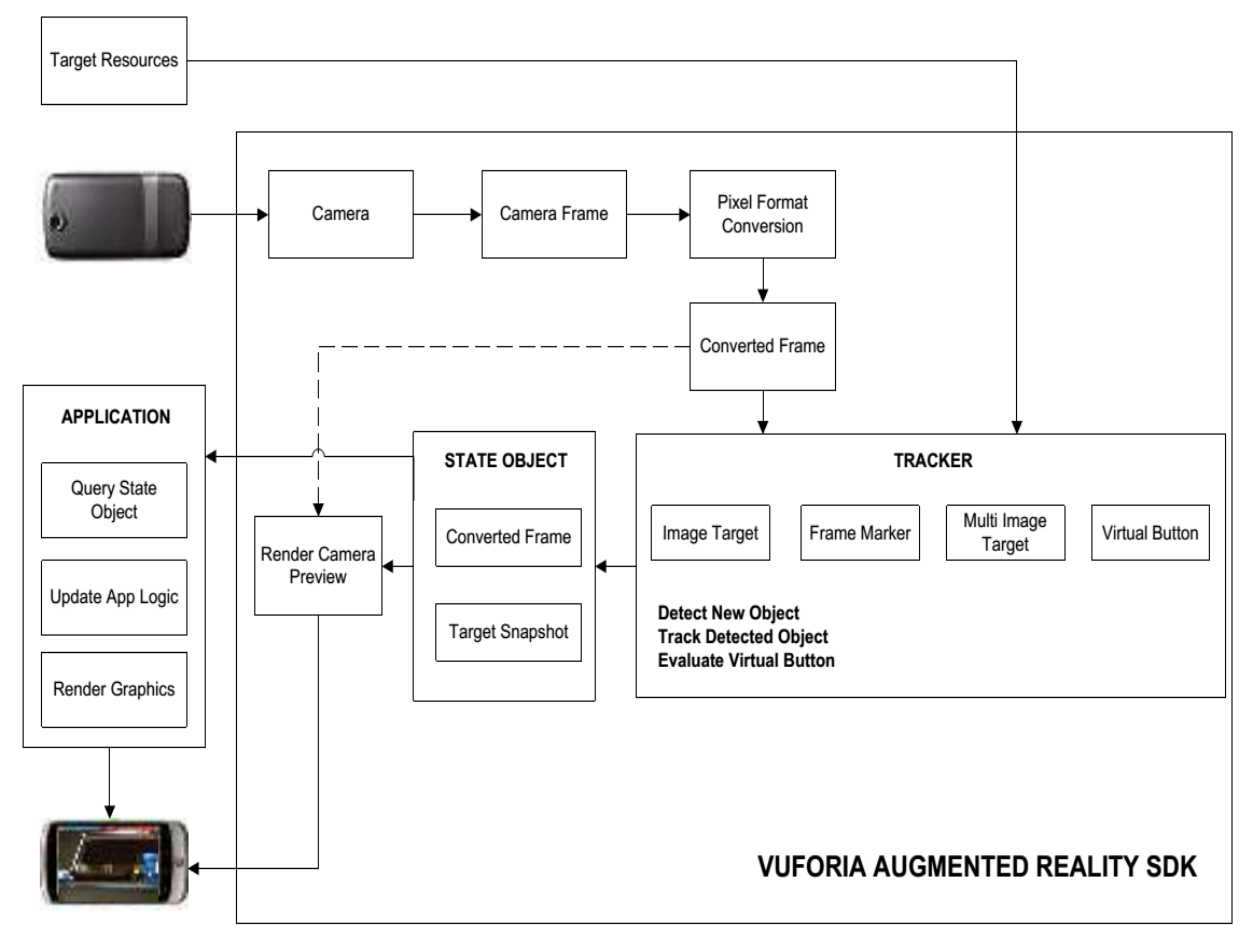

Gambar 8. Blok diagram pelacakan QCAR

Dari blok diagram Gambar 8 dapat dilihat bahwa pada sebuah aplikasi AR berbasis QCAR SDK terdiri dari komponen inti sebagai berikut:
a. Kamera.
b. Image Converter.
c. Tracker.
d. Video Background Renderer.
e. Application Code dan 


\section{f. Target resource.}

\section{Implementasi Program Dan Pengujian Aplikasi}

\subsection{Implementasi Program}

Sebuah program atau dalam Unity disebut dengan script, dimana script hanya berfungsi mengikuti aplikasi yang membawanya, dalam kasus ini adalah Unity, jadi script di dalam Unity tidak bisa di bawa ke program lain selain Unity. Didalamnya terdapat Scene-Scene yang berguna untuk menyimpan pada proses pembuatan aplikasi. Scene-Scene yang akan di buat pada aplikasi Catalog ini dapat di pada Gambar 9 berikut:

\begin{tabular}{|c|c|c|}
\hline Nama Scene & $\begin{array}{l}\text { Tingliatan/ } \\
\text { Level Scene }\end{array}$ & Deskripsi \\
\hline Mern_1. Unty & 0 & $\begin{array}{l}\text { Menerppillan halaman anal aplicasi } \\
\text { (Sglash Scroun) }\end{array}$ \\
\hline Menu_ 2 Unity & 1 & $\begin{array}{l}\text { Menumpilkan halaman Sora utuma } \\
\text { aplikati (Home) }\end{array}$ \\
\hline Howse Unity & 2 & 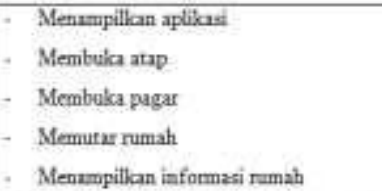 \\
\hline Panduan_1.Chiby & 3 & $\begin{array}{l}\text { Menumpilian isi foul pandian pada } \\
\text { halaman pertama }\end{array}$ \\
\hline Panduan_2Unity & 4 & $\begin{array}{l}\text { Menampilikan isi dan jandaan pada } \\
\text { halaman kedua }\end{array}$ \\
\hline
\end{tabular}

Gambar 9. Scene-Scene Dalam Aplikasi

a. Script Pada Scene Menu_1.Unity

Scene Menu_1.Unity dibuat untuk menampilkan SplashScreen saat aplikasi dibuka dan setelah beberapa waktu akan berpindah untuk menampilkan Menu Utama Aplikasi. Untuk lebih jelasnya tentang script pada dapat dilihat pada Gambar 10 berikut ini:

\begin{tabular}{|c|c|c|}
\hline Deskripsi & Filescript & Pernindahan Scene \\
\hline $\begin{array}{l}\text { Menampilkan SplashScreen yang } \\
\text { merupakan tampilan pembuka } \\
\text { aplikasi. }\end{array}$ & Spiashicreen.cs & $\begin{array}{c}\text { Level 1 } \\
\text { (Mens_1. Uniay) }\end{array}$ \\
\hline
\end{tabular}

Gambar 10. Scene Menu_1.Unity (SplashScreen)

b. Script Pada Scene Menu_2.Unity

Scene ini dibuat untuk mengatur atau memberikan event pada tiap-tiap Button. Untuk lebih jelasnya tentang script dapat dilihat pada Gambar 11 berikut ini:

\begin{tabular}{|c|c|c|c|}
\hline Sub . Thania & Deaknped & Preseruir & Beppintahad Scenx \\
\hline Sharr & $\begin{array}{l}\text { Metimmpilian Obect } \\
\text { numat 3D }\end{array}$ & Xema & Lonw/2 (Hanare. $($ hrov) \\
\hline Wandein & 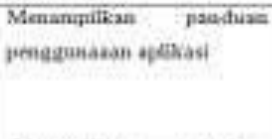 & Asmia & 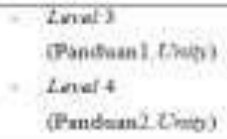 \\
\hline $\begin{array}{l}\text { Tetitane } \\
\text { Kanei }\end{array}$ & 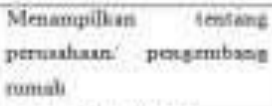 & SKen: as & 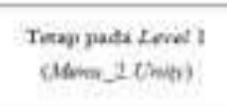 \\
\hline$E+0$ & Keluar dari apdicasi & Kame o & - \\
\hline
\end{tabular}

Gambar 11. Sub Menu Scene Menu_2.Unity 


\section{c. Script Pada Scene House. Unity}

Scene House.Unity ini dibuat Script dengan nama ARMenu.cs. Untuk lebih jelasnya dapat dilihat pada Gambar 12 berikut ini:

\begin{tabular}{|c|c|c|c|}
\hline Buttors & Deskripsí & Fite Script & Perpindahan Scene. \\
\hline Howe & $\begin{array}{l}\text { Kembali ke Masin menu } \\
\text { (Home) }\end{array}$ & ARMones cs & Level 1 (Menu_2.tinig) \\
\hline Erit & Keluar dari aplikasi & ARMorecs & - \\
\hline
\end{tabular}

Gambar 12. Button pada Scene House.Unity

Selain membuat Script ARMenu.cs, untuk menambahkan 2 buah Button Touch pada Scene House.Unity, disini juga kita membuat 2 buah Script yaitu RoofControl.cs PagarControl.cs. Untuk lebih jelasnya dapat dilihat pada Gambar 13 berikut ini:

\begin{tabular}{|c|c|c|c|}
\hline Bagian Tonch & Deskripsi & File Script & Penpindahan Scene \\
\hline Atap & Membuka atap & RoofCantrotes & $\begin{array}{c}\text { Tetap pade Level } 2 \\
\text { (House Lnity) }\end{array}$ \\
\hline Pintu Pagar & Membuka pagar & PagarControles & $\begin{array}{c}\text { Tetap pade Level } 2 \\
\text { (Honse Lnity) }\end{array}$ \\
\hline
\end{tabular}

Gambar 13. Fitur Touch pada Scene House. Unity

Pada Script PagarControl.cs memiliki tujuan yang sama dengan RoofControl.cs, maka untuk script pun sama. Hanya saja berbeda dalam pemberian nama class dan object nya. Selain itu juga ditambahkan fitur untuk menampilkan detail dari masing-masing rumah. Untuk lebih jelasnya dapat dilihat pada Gambar 14 berikut ini:

\begin{tabular}{|c|c|c|c|}
\hline Buton 3D & Deskripsi & Fìle Scrept & Perpindakan Scerse \\
\hline Kivk Info Disini & $\begin{array}{l}\text { Menampillan } \\
\text { infommasi rumah }\end{array}$ & InfoKlikl.cs & $\begin{array}{c}\text { Tetap pada Level } 2 \\
\text { (House.Lring) }\end{array}$ \\
\hline
\end{tabular}

Gambar 14. Fitur Button 3D pada Scene House.Unity

Untuk membuat tampilan model rumah lebih interaktif, maka ditambahkan 1 buah fitur tambahan lagi yaitu button rotasi Untuk lebih jelasnya dapat dilihat pada Gambar 15 berikut ini:

\begin{tabular}{|l|l|l|c|}
\hline Button Fitur & \multicolumn{1}{|c|}{ Deshripi } & File Script & Penindahan Scene \\
\hline Rotasi & $\begin{array}{l}\text { Nemutar object } \\
\text { Rumah }\end{array}$ & Rotarics & $\begin{array}{c}\text { Tetap pada Level 2 } \\
\text { (House Ching) }\end{array}$ \\
\hline
\end{tabular}

Gambar 15. Fitur Button 3D pada Scene House.Unity

\section{d. Script Pada Scene House. Unity}

Pada Scene Panduan_1.Unity ini dibuat Script dengan nama Panduan1.cs. Untuk lebih jelasnya dapat dilihat pada Gambar 16 berikut ini: 


\begin{tabular}{|c|c|c|c|}
\hline Bustion & Deskripsi & Fíe Script & Perpindahan Scense \\
\hline Home & $\begin{array}{l}\text { Kembali ke Man menu } \\
\text { (Home) }\end{array}$ & Panduan_los & $\begin{array}{c}\text { Level 1 } \\
\text { (16ru_ 2 Ling) }\end{array}$ \\
\hline Pandsuan2 & $\begin{array}{l}\text { Untuk ke balaman } \\
\text { selanjutnya }\end{array}$ & Panduan_lcs & $\begin{array}{c}\text { Leval3 } \\
\text { (Pandan_2 Uniny) }\end{array}$ \\
\hline
\end{tabular}

Gambar 16. Button pada Scene Panduan_1.Unity

e. Script Pada Scene Panduan_2.Unity

Pada Scene Panduan_2.Unity ini dibuat Script dengan nama Panduan2.cs. Untuk lebih jelasnya dapat dilihat pada Gambar 17 berikut ini :

\begin{tabular}{|c|c|c|c|}
\hline Sub $168 \mathrm{~min}$ & Deshingsi & File Seript & Pepindahan Scose \\
\hline Paxssoun & $\begin{array}{l}\text { Untuk ke kembali ke } \\
\text { halaman patama }\end{array}$ & Pandan_ 2.os & $\begin{array}{c}\text { Level3 } \\
\text { (Pandian 1.Vinty) }\end{array}$ \\
\hline
\end{tabular}

Gambar 17. Sub Menu Scene Panduan_2.Unity

Pada Script Panduan_2.cs ini memiliki struktur yang sama dengan Panduan_1, hanya nama class, button serta perpindahannya saja yang berbeda.

\subsection{Pengujian Fungsionalitas}

Pengujian menggunakan Smartphone Android dengan Android Versi Jelly Bean. Tampilan Marker pada halaman Catalog dapat dilihat pada Gambar 18 sedangkan untuk pengujiannya dapat dilihat pada Gambar 19 berikut ini:

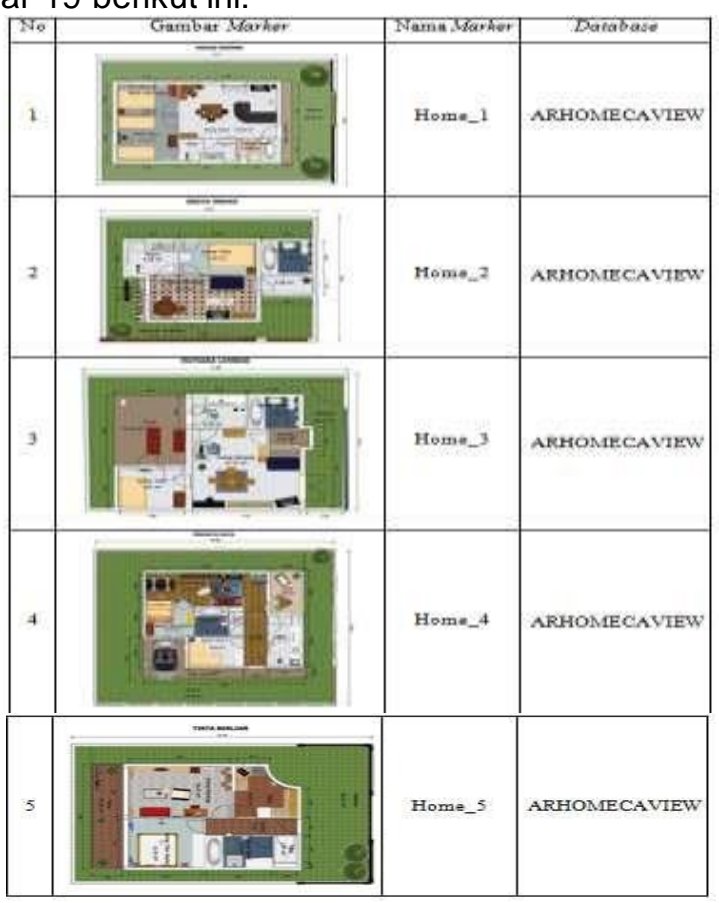

Gambar 18. Marker Aplikasi Catalog 3D Design Rumah 


\begin{tabular}{|c|c|c|c|}
\hline Pengujian & Bentuk Pengujian & $\begin{array}{l}\text { Hasil yang di } \\
\text { harapkan }\end{array}$ & $\begin{array}{c}\text { Hasil } \\
\text { Pengujian }\end{array}$ \\
\hline $\begin{array}{l}\text { Install Aplikasi } \\
\text { ARHOMECAVIEW. } \\
\text { apk pada Smartphone } \\
\text { Android }\end{array}$ & $\begin{array}{l}\text { Memasukkan dan } \\
\text { menginstall } \\
\text { ARHOMECAVIEW. } \\
\text { apk }\end{array}$ & $\begin{array}{l}\text { Proses instalasi dan } \\
\text { terpasang pada } \\
\text { Smartphone Anaroid } \\
\text { dengan baik. }\end{array}$ & Berhasil \\
\hline $\begin{array}{l}\text { Menjalankan aplikasi } \\
\text { yang terpasang }\end{array}$ & Membuka aplikasi & $\begin{array}{l}\text { Berjalan, aplikasi } \\
\text { dapat terbuka } \\
\text { dengan baik dan } \\
\text { Splash Screen } \\
\text { tampil. }\end{array}$ & Berhasil \\
\hline Menu Utama (Home) & Membuka aplikasi & $\begin{array}{l}\text { Muncul tampilan } \\
\text { Menu Utama, 3s } \\
\text { setelah } \\
\text { SplashScreen }\end{array}$ & Berhasil \\
\hline Button Start disentuh & $\begin{array}{l}\text { Menyentuh button } \\
\text { Start }\end{array}$ & $\begin{array}{l}\text { Muncul tampilan } \\
\text { aplikasi }\end{array}$ & Berhasil \\
\hline $\begin{array}{l}\text { Pendeteksian pada } \\
\text { Catalog (Marker) } \\
\text { yang dibuat dan telah } \\
\text { di tentukan }\end{array}$ & $\begin{array}{l}\text { Mengarahkan kamera } \\
\text { Smartphone ke } \\
\text { Catalog (Marker) } \\
\text { yang dibuat dan telah } \\
\text { di tentukan }\end{array}$ & $\begin{array}{l}\text { Keluar objek rumah } \\
\text { atau desain 3D }\end{array}$ & Berhasil \\
\hline $\begin{array}{l}\text { Pendeteksian pada } \\
\text { Catalog (Marker) } \\
\text { yang berbeda }\end{array}$ & $\begin{array}{l}\text { Mengarahkan kamera } \\
\text { Smartphone ke } \\
\text { Catalog (Marker) } \\
\text { yang berbeda }\end{array}$ & $\begin{array}{l}\text { Tidak dapat keluar } \\
\text { objek rumah atau } \\
\text { denah 3D }\end{array}$ & Berhasil \\
\hline \multirow[t]{2}{*}{$\begin{array}{l}\text { Membuka bagian } \\
\text { Atap rumah }\end{array}$} & $\begin{array}{l}\text { Mengarahkan kamera } \\
\text { Smartphone ke salah } \\
\text { satu gambar pada }\end{array}$ & $\begin{array}{l}\text { Atap terbuka dan } \\
\text { bagian dalam rumah } \\
\text { terlihat }\end{array}$ & Berhasil \\
\hline & $\begin{array}{l}\text { Catalog (Marker), } \\
\text { kemudian menyentuh } \\
\text { bagian atap pada } \\
\text { Smartphone. }\end{array}$ & & \\
\hline $\begin{array}{l}\text { Membuka bagian } \\
\text { Pagar rumah }\end{array}$ & $\begin{array}{l}\text { Mengarahkan kamera } \\
\text { Smartphone ke salah } \\
\text { satu gambar pada } \\
\text { Catalog (Marker), } \\
\text { kemudian menyentuh } \\
\text { bagian pintu pagar } \\
\text { pada Smartphone. }\end{array}$ & Pagar terbuka & Berhasil \\
\hline $\begin{array}{l}\text { Menampilkan } \\
\text { informasi detail } \\
\text { rumah }\end{array}$ & $\begin{array}{l}\text { Mengarahkan kamera } \\
\text { Smartphone ke salah } \\
\text { satu gambar pada } \\
\text { Catalog (Marker), } \\
\text { kemudian menyentuh } \\
\text { button Klik Info } \\
\text { Disini. }\end{array}$ & $\begin{array}{l}\text { Keluar tampilan } \\
\text { informasi dari } \\
\text { rumah }\end{array}$ & Berhasil \\
\hline Memutar rumah & $\begin{array}{l}\text { Mengarahkan kamera } \\
\text { Smartphone ke salah } \\
\text { satu gambar pada } \\
\text { Catalog (Marker), } \\
\text { kemudian menyentuh } \\
\text { button Rotasi. }\end{array}$ & $\begin{array}{l}\text { Object rumah } \\
\text { berputar searah } \\
\text { jarum jam }\end{array}$ & Berhasil \\
\hline
\end{tabular}

Gambar 19. Hasil Pengujian Fungsionalitas Aplikasi ARHOMECAVIEW

Pada Gambar 19 adalah hasil pengujian fungsionalitas aplikasi. Dan dapat disimpulkan bahwa penguijan fungsionalitas ini berjalan sesuai harapan yaitu sukses semua.

\subsection{Pengujian Marker Sketsa dan Foto Rumah}

Pengujian dilakukan dengan menambahkan beberapa Marker yang berbeda dengan yang pada Catalog dan dengan format model rumah yang berbeda pula. Tampilan Marker dapat dilihat pada Gambar 20 dan hasil pengujian Marker dapat dilihat pada Gambar 21 berikut: 


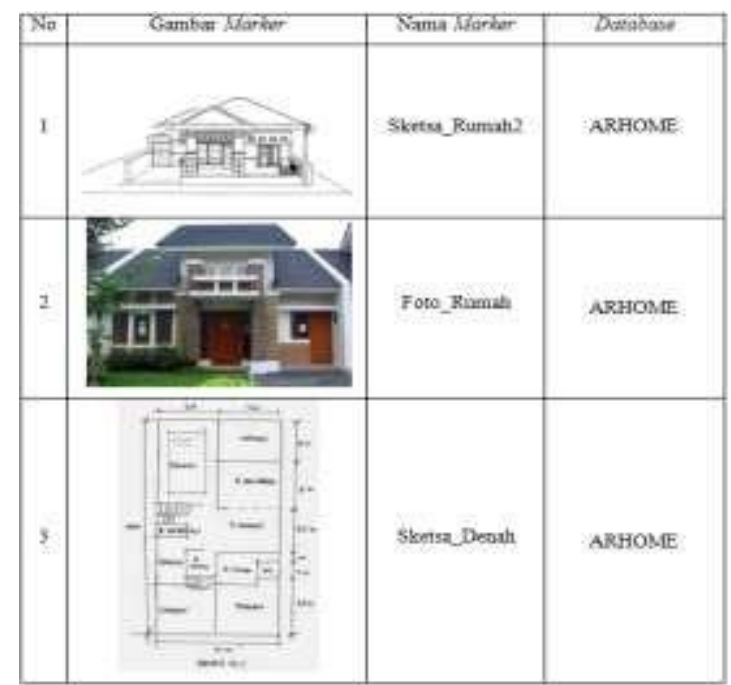

Gambar 20. Marker Sketsa dan Foto Rumah

\begin{tabular}{|c|c|c|c|}
\hline Penguian & Bentrik Penguian & $\begin{array}{l}\text { Hasil yang di } \\
\text { harrepican }\end{array}$ & $\begin{array}{c}\text { Hast } \\
\text { Pengujian }\end{array}$ \\
\hline $\begin{array}{l}\text { Pendeteksian pada } \\
\text { Caralog (Jianker) }\end{array}$ & $\begin{array}{l}\text { Mengarahican kamera } \\
\text { Smartchene ke } \\
\text { Catalog (Morbsr) }\end{array}$ & $\begin{array}{l}\text { Keloar objek rumah } \\
\text { atus decain 3D }\end{array}$ & Bentasti \\
\hline $\begin{array}{l}\text { Menaenpilkan objek. } \\
\text { nomat atan desain 3D }\end{array}$ & $\begin{array}{l}\text { Mengarahoin kamera } \\
\text { Smartphose ke } \\
\text { Catiolog (Markar) }\end{array}$ & $\begin{array}{l}\text { Keluar objek rumah } \\
\text { atwa desain 3D }\end{array}$ & Berhasil \\
\hline
\end{tabular}

Gambar 21. Hasil Pengujian Marker

Pada Gambar 21 adalah hasil pengujian Marker dengan menggunakan sketsa dan foto rumah. Dan dapat disimpulkan bahwa penguijan Marker dengan sketsa dan foto rumah ini berjalan sesuai harapan yaitu sukses semua.

\subsubsection{Pengujian Pada Smartphone}

Pada Gambar 22 a dan b adalah tampilan dari aplikasi ARHOMECAVIEW, Aplikasi Catalog $3 \mathrm{D}$ desain rumah yang dibuat menggunakan Unity $3 D$ dan berjalan pada Smartphone Android.

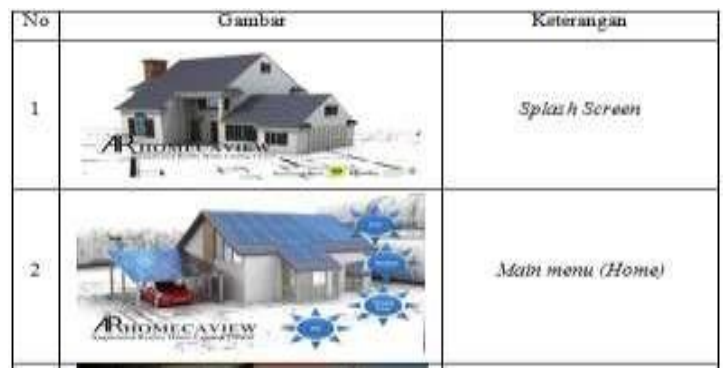

Gambar 22a. Tampilan Aplikasi ARHOMECAVIEW pada Smartphone 


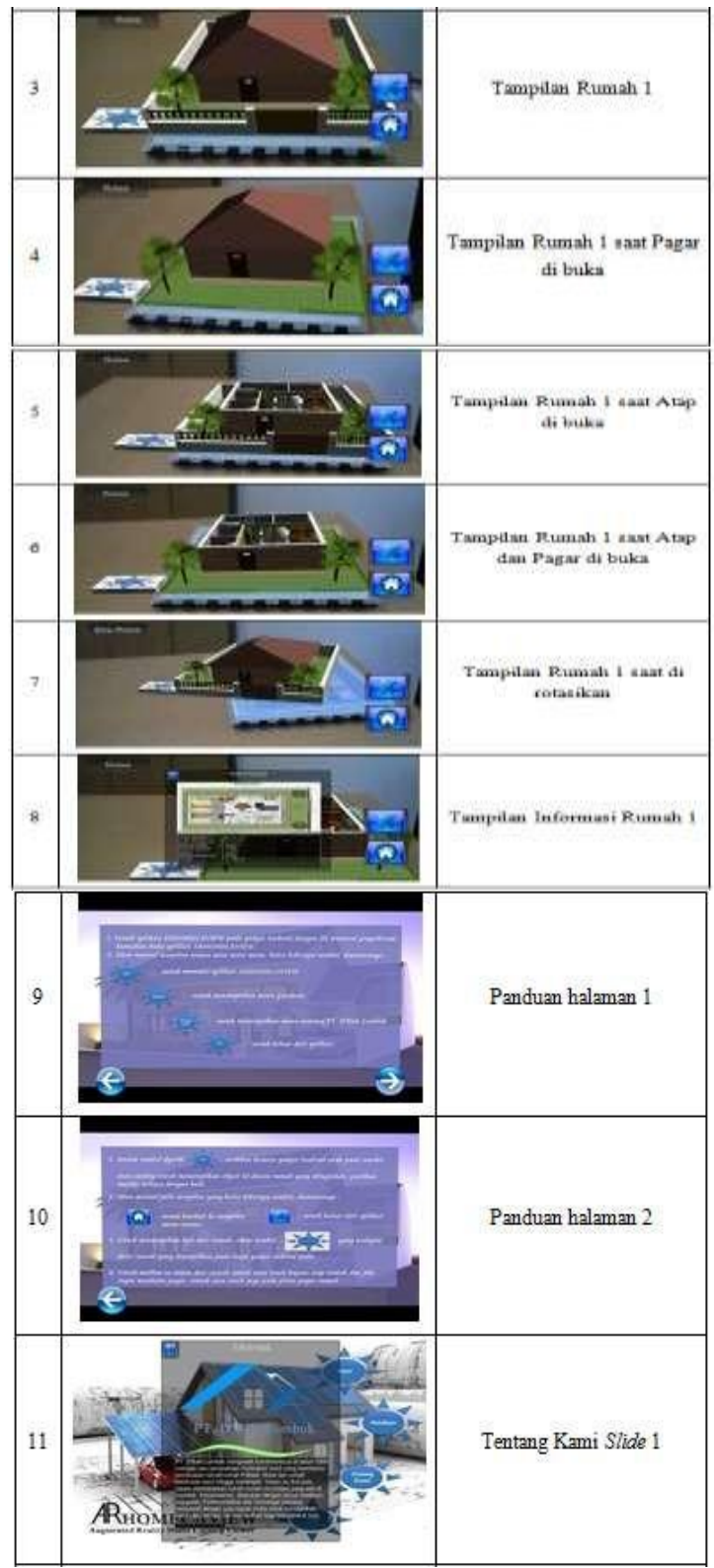

Gambar 22b. Tampilan Aplikasi ARHOMECAVIEW pada Smartphone

\subsubsection{Pengujian Masing-Masing Marker}

Pada Gambar 23 a dan b adalah tampilan dari model desain rumah yang ditampilkan pada masing- masing Marker yaitu gambar Marker yang dibuat dari hasil render Sweet Home 3D dan gambar sketsa serta foto rumah, berikut tampilannya:

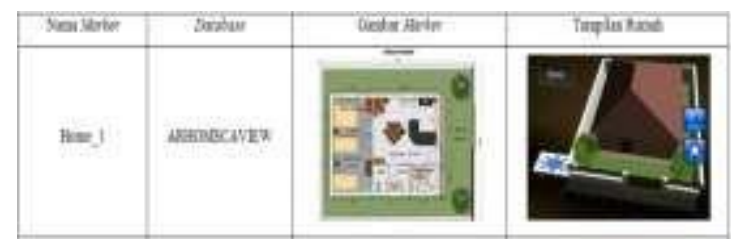

Gambar 23 a. Tampilan Model Desain Rumah Pada Masing- Masing Marker 


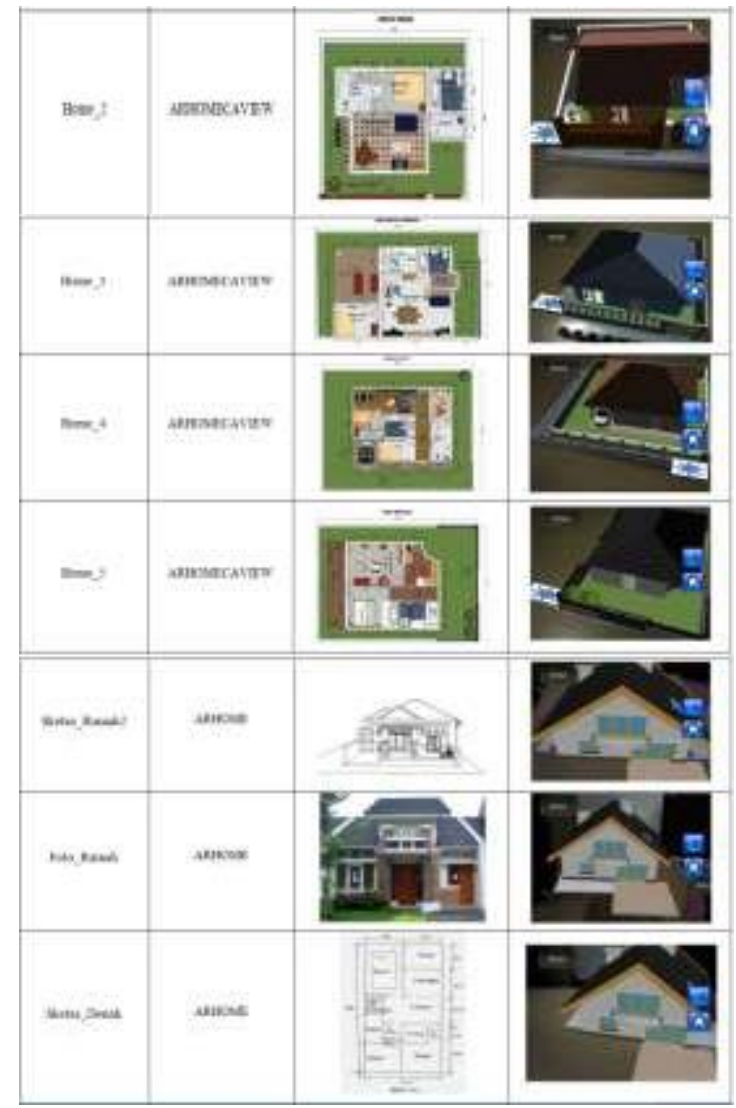

Gambar 23b. Tampilan Model Desain Rumah Pada Masing- Masing Marker

Berdasarkan Gambar 23 dapat dilihat bahwa masing-masing Marker dapat memunculkan object rumah sesuai dengan yang diharapkan.

\section{Kesimpulan}

Berdasarkan pembahasan dan pengujian aplikasi pada penelitian ini, dapat diperoleh kesimpulan sebagai berikut: pembuatan aplikasi menggunakan Unity $3 D$ dalam pemanfaatan teknologi Augmented Reality baik dalam pembuatan antarmuka, object rumah, button dan script untuk tampilan serta fitur pada aplikasi ini berjalan sesuai dengan perancangan, yaitu dapat menggabungkan objek 3D rumah yang bersifat virtual dengan dunia nyata. Secara keseluruhan fugsionalitas dari masing-masing bagian dapat berjalan pada Smartphone Android dengan baik. Pada pengujian Marker untuk menampilkan object rumah baik yang dibuat menggunakan Tools Sweet Home $3 D$ maupun Blender dapat berjalan dan berhasil ditampilkan. Pengujian pada Marker yang dibuat secara digital, sketsa tangan dan foto dapat dijadikan Marker dan dilacak dengan baik.

\section{Daftar Pustaka}

[1] B. T. Gorbala and M. Hariadi, "Aplikasi Augmented Reality untuk Katalog Penjualan Rumah," ITS Surabaya, 2010.

[2] U. M. Malang, M. Fathoni, E. B. Cahyono, S. Kom, and W. A. Kusuma, "ALAT MUSIK PERKUSI AUGMENTED REALITY BERBASIS ANDROID," Jurnal Teknologi Inform. Univ. Muhammadiyah Malang, 2012.

[3] C. Patrik et al., "Visualisasi 3 Dimensi Desain Interior Perabotan Rumah Berbasis Augmented Reality Pada Mobile Phone Dengan Sistem Operasi Android," Jurnal Skripsi Jurusan Teknik Informatika, pp. 1-8, 2013.

[4] B. Hariyanto, Rekayasa Sistem Berorientasi Objek. Bandung: Informatika, 2007. 